\title{
Improving Product Ad Design Capability for Indonesian Muslim Entrepreneurs (IPEMI) Medan Using Android-Based Applications
}

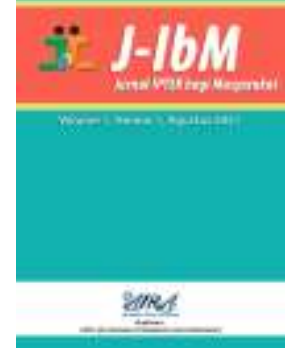

\author{
Aninda Muliani, Triase, Adnan Buyung Nasution, Samsudin, Suendri \\ Universitas Islam Negeri Sumatera Utara; Medan; 20731; Indonesia \\ *Correspondence: anindamh@uinsu.ac.id \\ https:journal.aira.or.id/J-IbM \\ Submission: 30-08-2021; Received : 31-08-2021; Accepted : 31-08-2021; Published : 31-08-2021
}

\begin{abstract}
The development of digital technology, especially digital multimedia, can change the way people do business. The development of social media and the sophistication of new applications offer endless opportunities for product marketing. Product marketing strategy is needed to increase competitiveness. One of the marketing strategies is attractive advertising media. This community service aims to improve the ability of home industry entrepreneurs who are members of the Medan IPEMI (Indonesian Islamic Entrepreneurs Association) organization to promote their products through advertising media. This activity teaches women entrepreneurs how to use the Kinemaster app to create product ads with visually appealing content. The resulting media is in the form of moving advertisements in short duration video formats.
\end{abstract}

Keywords: Digital Multimedia, Business, Strategy, Mobile Advertising

\section{Peningkatan Kemampuan Desain Iklan Produk pada Pengusaha Muslimah Indonesia (IPEMI) Medan Menggunakan Aplikasi Berbasis Android}

\begin{abstract}
Abstrak: Perkembangan teknologi digital, khususnya multimedia digital, dapat mengubah cara orang berbisnis. Perkembangan media sosial dan kecanggihan aplikasi baru menawarkan peluang tak terbatas untuk pemasaran produk. Dibutuhkan strategi pemasaran produk untuk meningkatkan daya saing. Salah satu strategi pemasaran adalah media iklan yang menarik. Pengabdian kepada masyarakat ini bertujuan untuk meningkatkan kemampuan para pengusaha home industry yang tergabung dalam organisasi IPEMI (Ikatan Pengusaha Islam Indonesia) Medan untuk mempromosikan produknya melalui media iklan. Kegiatan ini mengajarkan pengusaha wanita cara menggunakan aplikasi Kinemaster untuk membuat iklan produk dengan konten visual yang menarik. Media yang dihasilkan berupa iklan bergerak dalam format video berdurasi singat.
\end{abstract}

Kata Kunci: Multimedia Digital, Bisnis, Strategi, Iklan Bergerak 
Page 33 of 5 | J-IbM: Jurnal IPTEK bagi Masyarakat, Volume 1, Nomor 1, Agustus 2021

\section{Pendahuluan}

Teknologi Informasi dan Komunikasi (TIK) yang berkembang sangat pesat selama satu dekade terakhir telah memberikan dampak yang besar di berbagai bidang kehidupan kita, seperti bisnis, hiburan, dan pendidikan (Surjono, 2017). Model bisnis yang sebelumnya bersifat manual menjadi digital cenderung lebih disukai oleh masyarakat karena informasi dan transaksi bisa dilakukan dengan mudah sehingga mempercepat proses bisnis. Hal itu membuat para pengusaha mulai belajar dan cepat beradaptasi dengan mengubah model proses produksi dan distribusinya menjadi berbasis digital, salah satunya dalam memasarkan produk. (Suyanto, 2003)

Perkembangan media sosial dan kecanggihan aplikasi baru menawarkan peluang tak terbatas untuk pemasaran produk. Strategi pemasaran produk penting untuk menjadi kompetitif. Salah satu strategi pemasaran produk adalah media iklan yang menarik (Suyanto, 2005). Namun, banyak perusahaan, terutama yang bergerak di industri rumah tangga, belum memiliki kemampuan untuk membuat desain iklan yang menarik. Misalnya, sebuah perusahaan di industri rumah tangga yang menjadi anggota organisasi IPEMI (Ikatan Pengusaha Islam Indonesia) Medan.

IPEMI adalah organisasi sosial yang didirikan untuk meningkatkan peran dan kontribusi pengusaha wanita Muslim dalam memperkuat perekonomian masyarakat Indonesia untuk kemandirian ekonomi dengan kepribadian dan karakter yang luar biasa. Keberadaan IPEMI sangat penting bagi perusahaan syariah di Indonesia. Hal ini karena IPEMI berpotensi menjadi wadah pengembangan sinergi dan jaringan usaha, termasuk meningkatkan daya saing usaha dalam menghadapi tantangan ekonomi global (Ipemi, 2021)

Para ibu pengusaha IPEMI masih menggunakan teks dalam mengiklankan produknya, sehingga calon pembeli kurang berminat dan mengakibatkan penjualan tidak berjalan seperti harapan. Hal itu dikarenakan calon pembeli tidak memiliki cukup waktu untuk membaca iklan berisi teks yang panjang walaupun penjual sangat ingin mengedukasi calon pembeli mengenai keunggulan produknya. Masalah tersebut bisa diatasi dengan mengubah iklan berbasis teks menjadi iklan bergerak berupa video berdurasi singkat dengan memanfaatkan aplikasi Kinemaster.

Aplikasi tersebut merupakan aplikasi Android yang digunakan untuk mengedit video dan tampilannya terbilang sederhana, namun memiliki fitur terbaik dalam desain iklan. Melalui aplikasi ini, pengguna dapat membuat proyek video selangkah demi selangkah mulai dari pemilihan video hingga edit, pemilihan tema, input filter, input audio hingga rendering hasil edit video. Kinemaster juga memiliki begitu banyak musik latar sehingga memudahkan pengguna yang ingin memberikan musik latar melalui Aset Musik, Aset SFX, rekaman, atau menggunakan musik yang tersimpan di memori. Kinemaster mendukung hampir semua jenis format media. Memasukkan media ke dalam aplikasi ini sangat mudah karena semua media yang tersimpan di smartphone atau memori eksternal Anda akan ditampilkan di jendela yang sama dan dipisahkan oleh direktori repositori. Aplikasi ini juga memiliki kemampuan untuk menambahkan dan memanipulasi teks dalam berbagai font dan gaya, memungkinkan Anda menggunakan aplikasi KineMaster untuk membuat pengeditan video Anda lebih lengkap (Rahman, 2021) 
Berdasarkan permasalahan di atas maka pengabdian kepada masyarakat adalah Sistem Informasi Universitas Islam Nasional Sumatera Utara Medan yang berjudul "Menggunakan Aplikasi Berbasis Android Untuk Meningkatkan Daya Desain Iklan Produk Bagi Pengusaha Syariah Indonesia (IPEMI) Medan" Pengajar program penelitian bertujuan untuk meningkatkan kemampuan para pebisnis untuk membuat iklan produk.

\section{Metode}

Untuk kegiatan pelatihan Peningkatan Kemampuan Desain Iklan Produk Pada Pengusaha Muslimah Indonesia (Ipemi) Medan ini, langkah-langkah penyelenggaraan pelatihan meliputi tahapan sebagai berikut:

1. Pembuatan bahan ajar untuk kegiatan pelatihan

Pada tahap ini, proses yang dilakukan adalah membuat bahan ajar untuk kegiatan pelatihan. Serta mempelajari penggunaan aplikasi Kinemaster yang akan digunakan dalam kegiatan pelatihan. Bahan ajar yang dibuat berupa video simulasi.

2. Uji coba pada laptop sewaan Jalankan tes untuk melihat apakah aplikasi Kinemaster berjalan dengan baik.

3. Pelaksanaan Pelatihan

Pelatihan dilaksanakan pada tanggal 10 Maret 2021 dari pukul 14:00 WIB sampai dengan pukul 17:00 WIB di Villa Wisata Gunung Pematang Johar Sawah Deli Serdang. Materi yang diberikan dalam kursus ini adalah: pengenalan aplikasi Kinemaster, penentuan ide desain iklan, pengumpulan elemen video dan penggunaan aplikasi.

Setelah selesai materi dibawakan, para ibu pengusaha diminta untuk membuat desain iklan bergerak sebagai media promosi produk yang dipasarkan.

\section{Hasil}

Hasil dari kegiatan pengabdian masyarakat ini, para pelaku bisnis khususnya aplikasi Kinemaster dapat meningkatkan kemampuannya dalam menggunakan aplikasi berbasis Android dari segi desain mobile advertising. Juga, wanita bisnis dapat meningkatkan kreativitas mereka dan memasukkannya ke dalam ide-ide desain mereka.

Berikut adalah materi simulasi pada saat pelatihan :

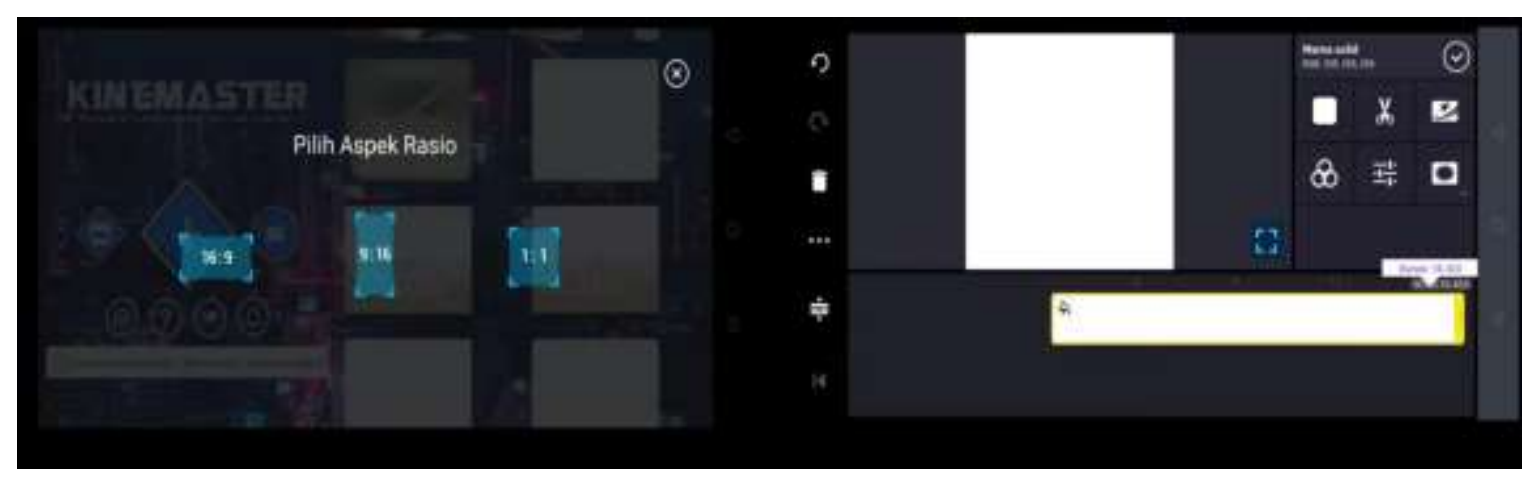

(a) 


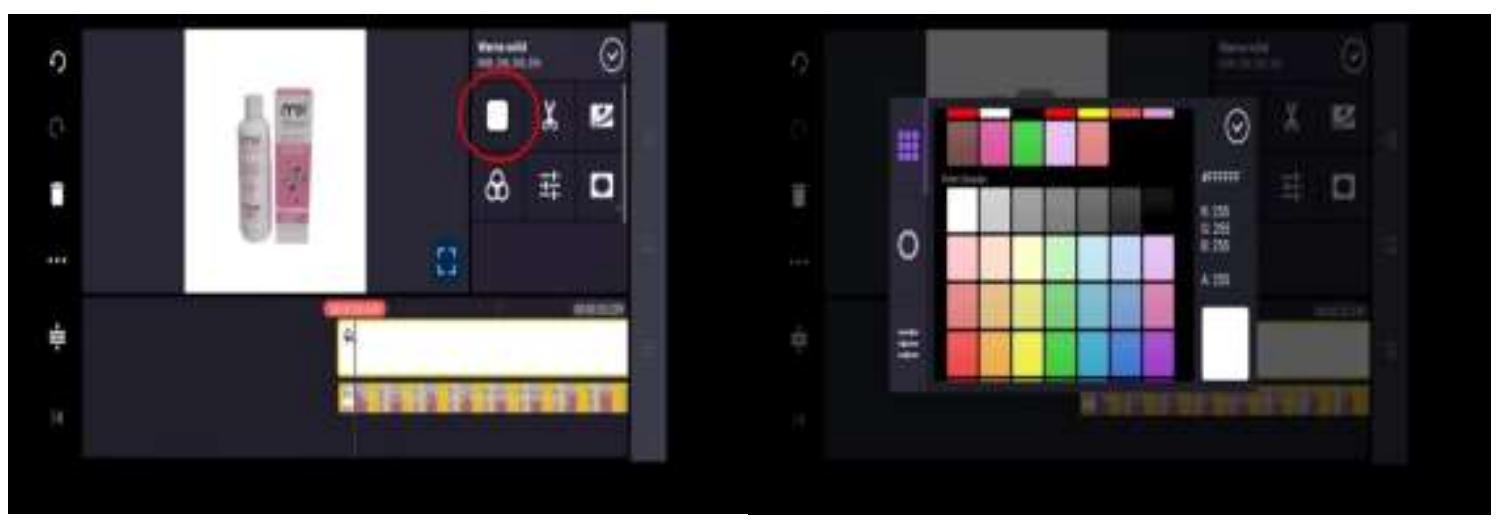

(b)

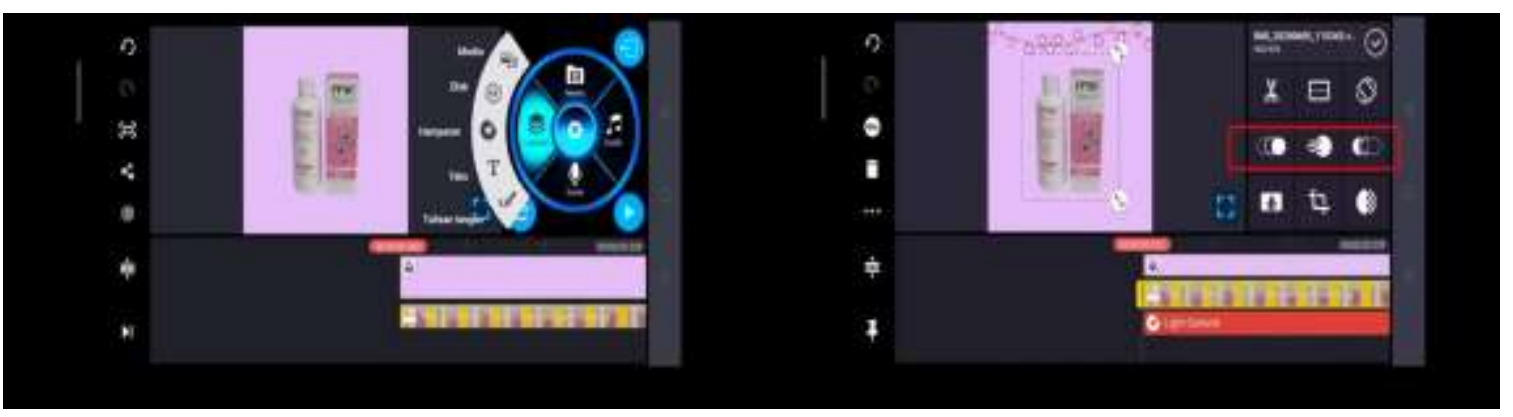

(c)

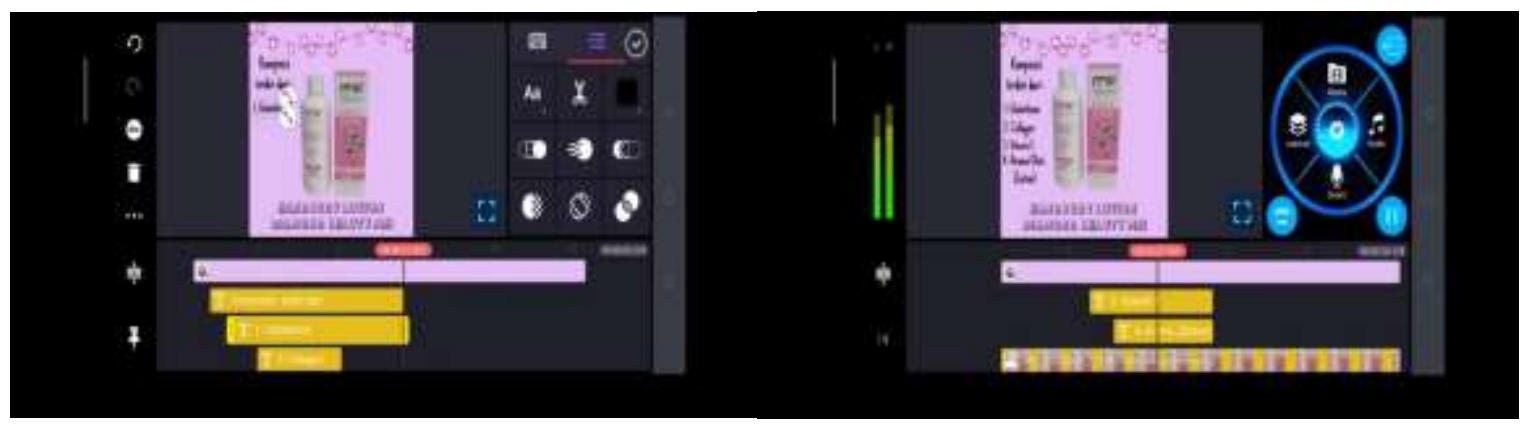

(d)

Gambar 1. (a) (b) (c) (d) Materi Pelatihan Pembuatan Iklan Produk

Berikut adalah contoh hasil desain dari peserta pelatihan :

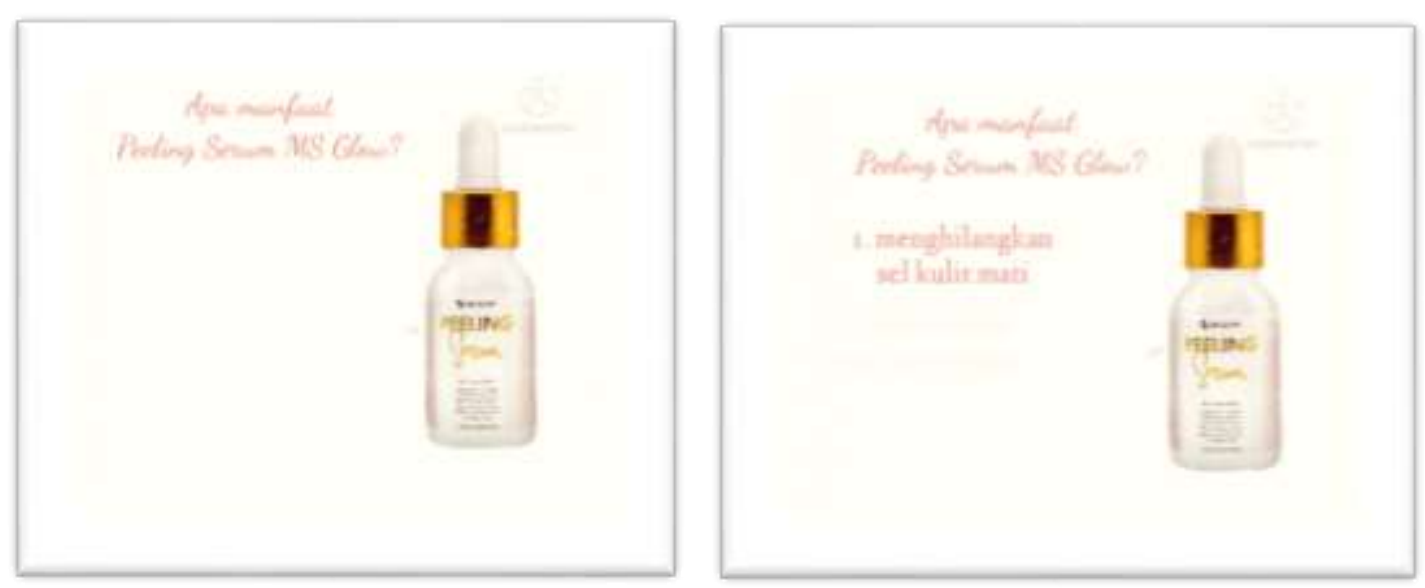

(a) 

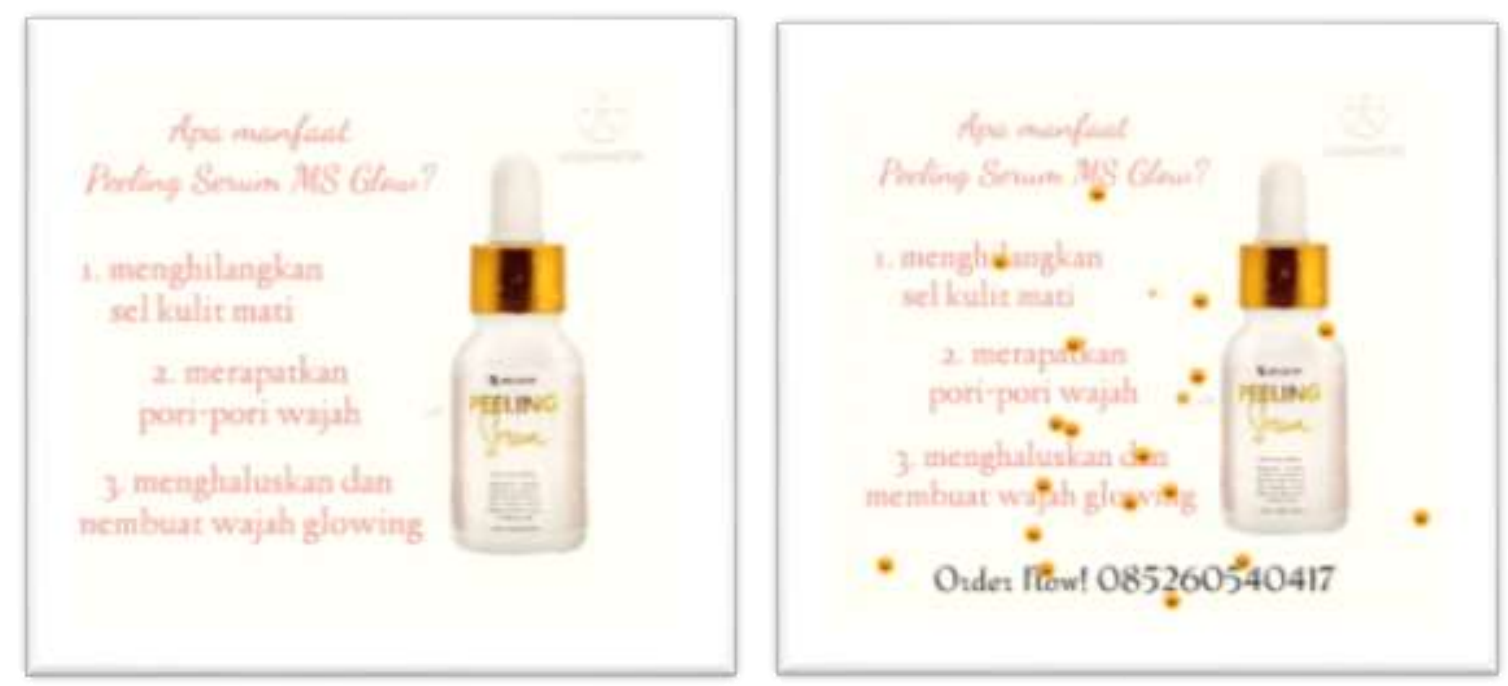

(b)

Gambar 2. (a) (b) Contoh Iklan Produk

\section{Kesimpulan}

Kesimpulan dari program pengabdian masyarakat ini adalah: (1) Peserta memahami prosedur penggunaan aplikasi Kinemaster. (2) Peserta pelatihan memahami cara mendesain menggunakan fungsi Kinemaster. Kami juga dapat menggunakan berbagai aplikasi seperti CapCut dan Instagram untuk pelatihan menyediakan layanan kami.

\section{Pengakuan/Acknowledgements}

Kami mengucapkan terima kasih kepada Ketua LPPM UIN SUMUT, Ketua IPEMI Sumut, Pengurus IPEMI Medan, para pengusaha yang tergabung dalam IPEMI Medan dan mahasiswa UIN Sumut Medan yang terlibat..

\section{Daftar Referensi}

Surjono, Herman Dwi. (2017). Multimedia Pembelajaran Interaktif. Yogyakarta: UNY Press.

Suyanto. (2003). Strategi Periklanan E-Commerce Perusahaan Top Dunia. Yogyakarta: Penerbit Andi.

Suyanto. (2005). Multimedia Alat untuk Meningkatkan Keunggulan Bersaing. Yogyakarta: Andi Offset.

Ipemi. (2021). About Ipemi. Diambil dari

https://ipemipp.or.id/about

Rahman, Su. (2021). Buku Pintar Video Editing di Android. Jakarta: Gramedia Pustaka Utama. 